\title{
Optical characteristics of biomass burning aerosols over Southeastern Europe determined from UV-Raman lidar measurements
}

\author{
V. Amiridis ${ }^{1}$, D. S. Balis ${ }^{2}$, E. Giannakaki ${ }^{2}$, A. Stohl ${ }^{3}$, S. Kazadzis ${ }^{2,4}$, M. E. Koukouli ${ }^{2}$, and P. Zanis ${ }^{5}$ \\ ${ }^{1}$ Institute for Space Applications and Remote Sensing, National Observatory of Athens, Athens, 15236, Greece \\ ${ }^{2}$ Laboratory of Atmospheric Physics, Aristotle University of Thessaloniki, Thessaloniki, Greece \\ ${ }^{3}$ Norwegian Institute for Air Research, Kjeller, Norway \\ ${ }^{4}$ Research and Development, Finnish Meteorological Institute, Helsinki, Finland \\ ${ }^{5}$ Dept. of Meteorology and Climatology, Aristotle University of Thessaloniki, Thessaloniki, Greece
}

Received: 14 July 2008 - Published in Atmos. Chem. Phys. Discuss.: 21 October 2008

Revised: 16 December 2008 - Accepted: 24 March 2009 - Published: 3 April 2009

\begin{abstract}
The influence of smoke on the aerosol loading in the free troposphere over Thessaloniki, Greece is examined in this paper. Ten cases during 2001-2005 were identified when very high aerosol optical depth values in the free troposphere were observed with a UV-Raman lidar. Particle dispersion modeling (FLEXPART) and satellite hot spot fire detection (ATSR) showed that these high free tropospheric aerosol optical depths are mainly attributed to the advection of smoke plumes from biomass burning regions over Thessaloniki. The biomass burning regions were found to extend across Russia in the latitudinal belt between $45^{\circ} \mathrm{N}-55^{\circ} \mathrm{N}$, as well as in Eastern Europe (Baltic countries, Western Russia, Belarus, and the Ukraine). The highest frequency of agricultural fires occurred during the summer season (mainly in August). The data collected allowed the optical characterization of the smoke aerosols that arrived over Greece, where limited information has so far been available. Two-wavelength backscatter lidar measurements showed that the backscatterrelated Ångström exponent ranged between 0.5 and 2.4 indicating a variety of particle sizes. UV-Raman lidar measurements showed that for smoke particles the extinction to backscatter ratios (so-called lidar ratios) varied between $40 \mathrm{sr}$ for small particles to $100 \mathrm{sr}$ for large particles. Dispersion model estimations of the carbon monoxide tracer concentration profiles for smoke particles indicate that the variability of the optical parameters is a function of the age of the smoke
\end{abstract}

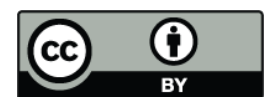

Correspondence to: V. Amiridis (vamoir@space.noa.gr) plumes. This information could be useful on the lidar community for reducing uncertainty in the aerosol backscatter coefficient determination due to the lidar ratio assumption, starting from a simply elastic backscatter lidar as the first satellite-borne lidar CALIPSO.

\section{Introduction}

Biomass burning is a major source of air pollution and the second largest source of anthropogenic aerosols (IPCC, 2001). The Fourth Assessment Report of the Intergovernmental Panel on Climate Change (Forster et al., 2007) reports a contribution of roughly $+0.04 \mathrm{~W} / \mathrm{m}^{2}$ of biomass burning aerosol to the global radiative forcing (RF) with a standard deviation of $0.07 \mathrm{~W} / \mathrm{m}^{2}$. This estimate of the direct $\mathrm{RF}$ is more positive than that of the Third Assessment Report (IPCC, 2001) and it is linked with improvements in the models in representing the absorption properties of biomass burning aerosol and the effects of their vertical distribution. Textor et al. (2006) showed that there are still significant uncertainties in the aerosol vertical distribution in global aerosol models, information that is critical in assessing the magnitude and even the sign of the direct RF of biomass burning aerosols.

In the last decade, a large number of biomass-burning studies concentrated on the physical, chemical, and thermodynamic properties of biomass-burning particles. A considerable body of research using in situ measurement techniques has been published on the optical properties of smoke.

Published by Copernicus Publications on behalf of the European Geosciences Union. 
This includes the analysis of laboratory burns (Patterson and McMahon, 1987) and intensive field campaigns involving large-scale forest fires in the North America (Hobbs et al., 1996), as well as over Brazil (Andreae et al., 1996; Kaufman et al., 1998) and over Africa (Eck et al., 2001). Finally, smoke studies using remote-sensing techniques have included ground-based sun photometry (Kaufman et al., 1992) and quantitative inversions of satellite imagery for smoke optical properties (Ferrare et al., 1990). A detailed review of biomass burning literature is presented in Reid et al. (2005a, b).

Studies mentioned above are referring to laboratory, insitu and columnar sunphotometric measurements mainly of fresh smoke. Smoke particles from biomass burning change rapidly in size and composition after being emitted into the atmosphere (Westphaal and Toon, 1991; Liousse et al., 1995; Hobbs et al., 1997; Reid et al., 1998). There are a variety of mechanical, chemical and thermodynamic processes that can alter smoke properties. Under most circumstances, measurements of the characteristics of fresh smoke plumes and laboratory burns cannot be assumed to be applicable to the aged smoke that is of greatest interest when studying its radiative effects or its impact on regional air quality (Reid et al., 2005a). Evidence suggests that most particle growth in size and mass occurs on fairly short time scales (Abel et al., 2003; Reid et al., 1998). Excluding scavenging processes, studies on smoke particle evolution and growth have focused on Brownian coagulation in dispersing plumes, and gas-toparticle conversion and exchange (e.g., Turco and Yu, 1997). These calculations indicate that after a plume has dispersed into a regional haze or is undergoing long-range transport, particle coagulation is the significant mechanism for particle growth over long enough timescales. If this evolution of smoke particles is not properly accounted for, large errors may result in calculations of their RF on regional and global scales (Müller et al., 2005)

For an accurate smoke characterization, first the smoke particles have to be identified in a non-mixed aerosol state and that can only be achieved by studying lofted smoke layers in the free troposphere on the basis of long-term observations by means of lidar technique. Up to date, only few lidar studies investigated the optical, radiative (Wandinger et al., 2002; Balis et al., 2003) and microphysical properties (Müller et al., 2005) of smoke particles in lofted layers. Mattis et al. (2003) reported on strongly enhanced values of particle backscattering and extinction in the free troposphere over Germany in spring/summer of the year 2003, when a large-scale event of free tropospheric transport of biomass burning particles from Siberia occurred. The above mentioned studies were based on Raman lidar observations carried out in the framework of the European Aerosol Research Lidar Network (EARLINET) (Bösenberg et al., 2003). Ground-based lidar measurements of particle optical properties with high spatial and temporal resolution give detailed information on the occurrence, extent and development of aerosol structures. EARLINET can follow the evolution of smoke plumes from Siberia and Russia over the European continent and report on changes of the optical properties of these particles with age.

Forest fires in Russia are a major source of pollution in the Northern Hemisphere (Wotawa et al., 2001). For that reason, there has been increased interest in recent years to assess the impact of these fires on climate (e.g. Kasischke and Bruhwiler, 2003). According to an investigation of the spatial and temporal occurrence of fires in croplands based on MODIS (Moderate Resolution Imaging Spectroradiometer) active fire product (Koronzi et al., 2006), the Russian Federation was found to be the largest contributor to agricultural burning globally during the period 2001 to 2003, producing $31-36 \%$ of all agricultural fires. This globally highest concentration of agricultural fires, found to be extended across Russia in the latitudinal belt between $45^{\circ} \mathrm{N}-55^{\circ} \mathrm{N}$ during the spring (April-May), as well as in Eastern Europe (Baltic countries, western Russia, Belarus, and the Ukraine) during the late summer (August).

In this study we present analyses of smoke optical properties measured over Southeastern Europe based on measurements of the EARLINET lidar station of Thessaloniki during ten episodes of very high free tropospheric aerosol optical depths (AOD) caused by the advection of air masses over Greece, mainly from biomass burning agricultural regions in Russia and Ukraine. In Sect. 2 we describe the instrumentation and the dispersion modeling tools used. Section 3 presents a smoke case study as an example of the analysis followed for all the days of our smoke measurements. The variability of the optical properties is then attributed to smoke ageing by coagulation leading to variable observed mixing state and size distribution of the agricultural fire aerosol investigated. Finally, our conclusions are given in Sect. 4.

\section{Instrumentation and methods}

\subsection{Description of the lidar system and lidar data pro- cessing}

At the Laboratory of Atmospheric Physics (LAP) $(50 \mathrm{~m}$ above sea level), Aristotle University of Thessaloniki, a $355 \mathrm{~nm}$ Raman-backscatter lidar is used to perform continuous measurements of suspended aerosols particles in the Planetary Boundary Layer (PBL) and the lower free troposphere (FT). It is based on the second and third harmonic frequency of a compact, pulsed Nd:YAG laser, which emits pulses of 300 and $120 \mathrm{~mJ}$ at $532 \mathrm{~nm}$ and $355 \mathrm{~nm}$, respectively, with a $10 \mathrm{~Hz}$ repetition rate (more technical details can be found on: Balis et al., 2000; Amiridis et al., 2005). The optical receiver is a $500 \mathrm{~mm}$ diameter telescope. The LAP lidar was successfully intercompared with other EARLINET instruments showing on the average an agreement of better than $5 \%$ for heights above $2 \mathrm{~km}$ in the backscatter coefficient 
(Matthias et al., 2004). The lidar-data handling procedures that are routinely used at LAP for the application of FernaldKlett and Raman retrieval methods were successfully tested by two algorithm intercomparisons that took place during the EARLINET project (Böckmann et al., 2004; Pappalardo et al., 2004) and include error estimates for all participating groups. According to these studies the mean deviation from the solution in the determination of the backscatter coefficient with the Klett method was $5.5 \%$ at $355 \mathrm{~nm}$ and $2.9 \%$ at $532 \mathrm{~nm}$, while the mean deviations from the solution for extinction at $355 \mathrm{~nm}$ with the Raman method was within $10 \%$ and $20 \%$ for boundary layer aerosol, reaching although even $40 \%$ for lofted layers, and for the solution of backscatter within $10 \%$ for all heights. The incomplete overlap between the laser beam and the receiver field of view affects significantly lidar observations of particle optical properties in the near-field range. At LAP we apply an overlap correction based on a technique proposed by Wandinger and Ansmann (2002), down to the height where the overlap function is equal to 0.5 . This correction allows extending the profile in most cases down to 1000-1500 m above sea level. An application of this methodology and its experimental verification is presented in Balis et al., (2002).

\subsection{Particle dispersion model and satellite hotspot de- tection}

To simulate transport processes, we employed the Lagrangian particle dispersion model FLEXPART (version 6.3) (Stohl et al., 1998; Stohl et al., 2005). Information on FLEXPART can be obtained via the internet at http://transport. nilu.no/flexpart. FLEXPART was driven here by operational analysis data from the European Centre for Medium-Range Weather Forecasts (ECMWF) model. The ECMWF data had 60 model levels and $1 \times 1$ degree global resolution. For the emission inputs for carbon monoxide, nitrogen oxides and sulfur dioxide, the Emission Database for Global Atmospheric Research (EDGAR) version 3.2 emission inventory for the year 2000 (fast track) on a $1 \times 1$ degree grid was used. Backward simulations were performed for $500-\mathrm{m}$ intervals along a vertically stacked array at the location of our surface station for times when particularly interesting measurements were obtained (see http://zardoz.nilu.no/ andreas/ EARLINET/). Every simulation consists of 40000 particles released in the volume of air sampled. The backward simulations were done with full turbulence and convection parameterizations. The mathematical theory of these computations is described in Seibert and Frank (2004), and an application to aircraft measurements was presented by Stohl et al. (2003). The model output is a sensitivity field of emission fluxes, which were stored on a 3-D grid with three altitude levels $(0-100 \mathrm{~m}, 100-3000 \mathrm{~m}$, and above) and a horizontal resolution of $1 \times 1$ degree globally $(0.5 \times 0.5$ degree resolution in a nest over the area of most interest). The emission sensitivity in the $0-100 \mathrm{~m}$ layer is of high interest since emis- sions typically occur at or near the ground. By multiplying the emission sensitivity value with the emission flux, a gridded source contribution field is obtained which, after spatial integration, yields a mixing ratio at the measurement site.

For estimating the smoke emission for the fires under study, we used fire count data from the low resolution Along Track Scanning Radiometers ATSR-2 onboard the ERS-2 satellite (2000-2002) and AATSR onboard ENVISAT (20032005). ATSR allows the detection of active fires using its thermal infrared channel centered at $3.7 \mu \mathrm{m}$. ATSR data was obtained from the Ionia website of European Space Agency, ESA (http://dup.esrin.esa.int/ionia/wfa/index.asp). Hotspot data used in this study were calculated with the version 2 algorithm that uses a detection threshold of $308^{\circ} \mathrm{K}$ (Dozier, 1981).

Following Seiler and Crutzen (1980) the emissions of carbon monoxide (CO) from the fires were estimated. $\mathrm{CO}$ is often used as a tracer for long-range pollution transport and will be used here to identify when and at what altitudes the atmosphere above Thessaloniki was affected by fire emissions. $\mathrm{CO}$ emissions were calculated using the equation:

$E=A B a b$

where $A$ is the area burned $\left(\mathrm{m}^{2}\right), B$ is the biomass per area $\left(\mathrm{kg} / \mathrm{m}^{2}\right), a$ is the fraction of the biomass consumed by the fire, and $b$ is the $\mathrm{CO}$ emission factor $(\mathrm{g} / \mathrm{kg})$. Every detected fire was linked to a certain land cover type, using a global land cover classification with a resolution of $1 \mathrm{~km}$ (Hansen et al., 2000), for which a certain biomass per area was assumed. The largest uncertainty in this calculation is the area burned for a detected hot spot, here taken to be 600 ha. Since this number is more or less arbitrary for the ATSR data, the resulting tracer concentrations are rather qualitative. The emission calculations (but based on MODIS hot spot data) are described in detail in Stohl et al. (2007).

\section{Results and discussion}

Regular aerosol extinction and backscatter measurements using a UV Raman lidar have been performed from January 2001 to December 2005 at Thessaloniki, Greece, in the framework of the EARLINET project. Dispersion model simulations showed that for ten days of our lidar measurements, smoke was advected over Thessaloniki from regions with strong fire activity in Eastern Europe and Russia. These dates of smoke presence and the main source of particles are presented in Table 1. The height ranges of smoke layers are additionally denoted in Table 1 along with the lidar derived mean values and standard deviations of optical parameters for the specific layers, namely the AOD, the mean lidar ratio and the mean backscatter related Ångström exponent.

Figure 1 shows an aggregate plot of all ATSR and AATSR fire detections for the ten days of the lidar measurements. Location of the burning regions was also verified by the 
Table 1. Dates of smoke presence over Thessaloniki, as indicated by the synergy of lidar measurements and dispersion modeling. The source of smoke particles is denoted along with the height range of smoke layers and the lidar derived optical parameters, namely the AOD, the mean lidar ratio and the mean backscatter-related Ångström exponent along with the sandard deviation of these values from vertical averaging.

\begin{tabular}{llcccc}
\hline Date & Source & Height range [km] & AOD & LR [sr] & Ångström \\
\hline 12 Jul 2001 & Russia & $2.12-3.83$ & 0.47 & $86 \pm 2$ & $1.39 \pm 0.02$ \\
16 Jul 2001 & Russia & $1.28-2.30$ & 0.25 & $71 \pm 8$ & $1.57 \pm 0.13$ \\
9 Aug 2001 & Ukraine & $1.67-3.47$ & 0.74 & $56 \pm 1$ & $1.71 \pm 0.26$ \\
16 Aug 2001 & Ukraine & $1.64-4.22$ & 0.71 & $78 \pm 14$ & $1.41 \pm 0.08$ \\
20 Aug 2001 & Russia & $2.42-4.73$ & 0.31 & $50 \pm 1$ & $1.80 \pm 0.06$ \\
8 Jul 2002 & Russia & $2.45-3.77$ & 0.20 & $76 \pm 3$ & $1.76 \pm 0.05$ \\
22 Aug 2002 & Ukraine & $2.63-4.10$ & 0.20 & $39 \pm 12$ & $2.20 \pm 0.21$ \\
28 Jul 2005 & Russia & $1.67-3.14$ & 0.52 & $69 \pm 12$ & $1.98 \pm 0.15$ \\
1 Aug 2005 & Russia & $2.21-3.17$ & 0.22 & $94 \pm 5$ & $0.78 \pm 0.25$ \\
12 Sep 2005 & Russia & $2.06-3.56$ & 0.28 & $53 \pm 6$ & $1.29 \pm 0.22$ \\
\hline
\end{tabular}

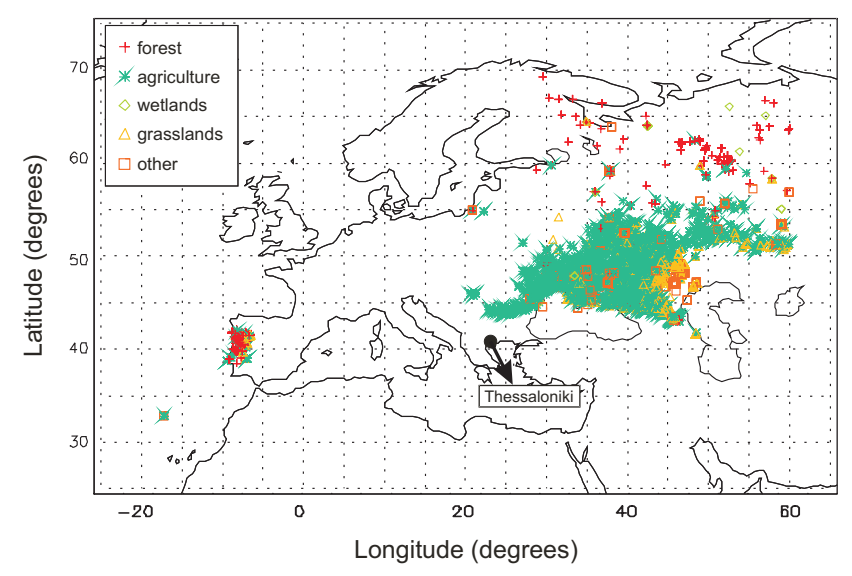

Fig. 1. Location of fires for the ten days of lidar measurements over Thessaloniki as detected by ATSR. Symbols indicate the dominant land cover where the detection occurred.

MODIS Fire Product (http://modis-fire.umd.edu/products. asp, not shown here). Symbols indicate the dominant land cover where the detection occurred based on a global land cover classification with a resolution of $300 \mathrm{~m}$ derived from the European Space Agency's Global Land Cover service for the production of global land-cover map for the year 2005, using ENVISAT MERIS Fine Resolution (300m) data that replaced the GlobCover 2000 product which had $1 \mathrm{~km}$ resolution (http://dup.esrin.esa.int/projects/-summaryp68.asp). Figure 1 strongly suggests that smoke particles discussed in this paper were produced mainly by agricultural burning activities.

To explore whether the observed aerosols in our lidar profiles were advected over Thessaloniki from the agricultural fires mentioned, the Lagrangian particle dispersion model FLEXPART was used. A case study example for the 20th August 2001 (18:00 UTC) is presented here to describe the analysis followed for the ten days used in this work. In Fig. 2

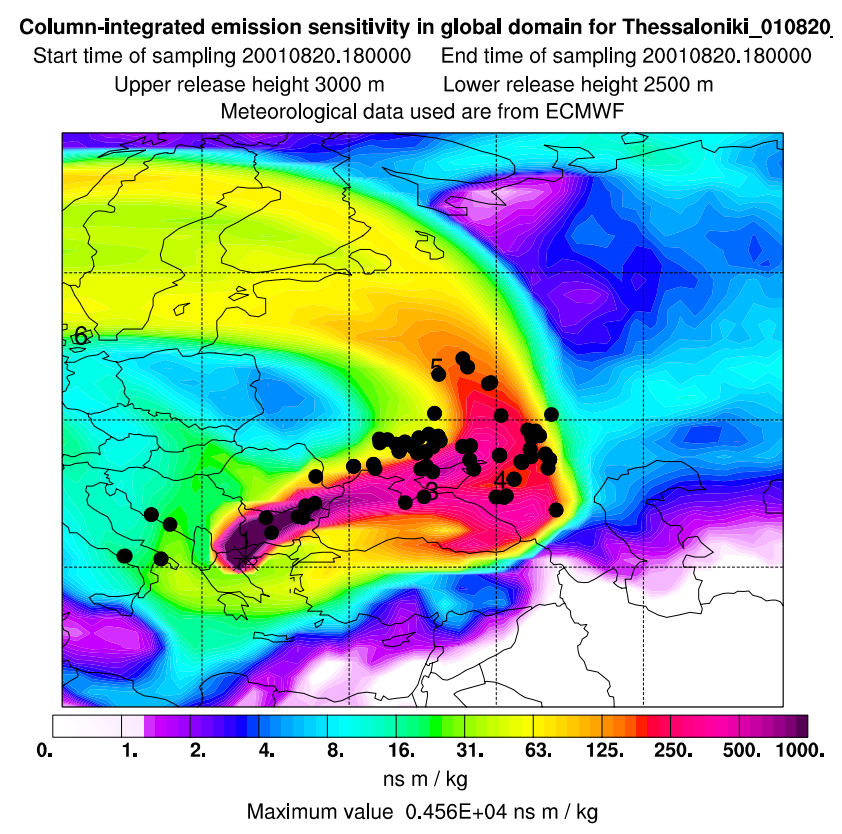

Fig. 2. Emission sensitivity obtained from the 20-day backward simulation with FLEXPART for the layer between 2500 and $3000 \mathrm{~m}$ on the 20th of August 2001 at 18:00 UTC. The column vertical emission sensitivity is shown. Numbers represent the days backward in time as plotted at the retroplume centroid location. Hot spots detected by ATSR are superimposed (black circles) only in grid cells where the daily column-integrated emission sensitivity on the very day of the hot spot identification is above $8 \mathrm{~ns} \mathrm{~m} / \mathrm{kg}$, indicating the significant possibility of smoke advection.

the column-integrated emission sensitivity obtained from the backward simulation with FLEXPART for the height range $2.5-3.0 \mathrm{~km}$ over Thessaloniki (corresponding simulations were done for all other $500 \mathrm{~m}$ intervals up to $10 \mathrm{~km}$ altitude) is presented along with the hot spots detected by ATSR, representing the position of fires as black dots. FLEXPART 

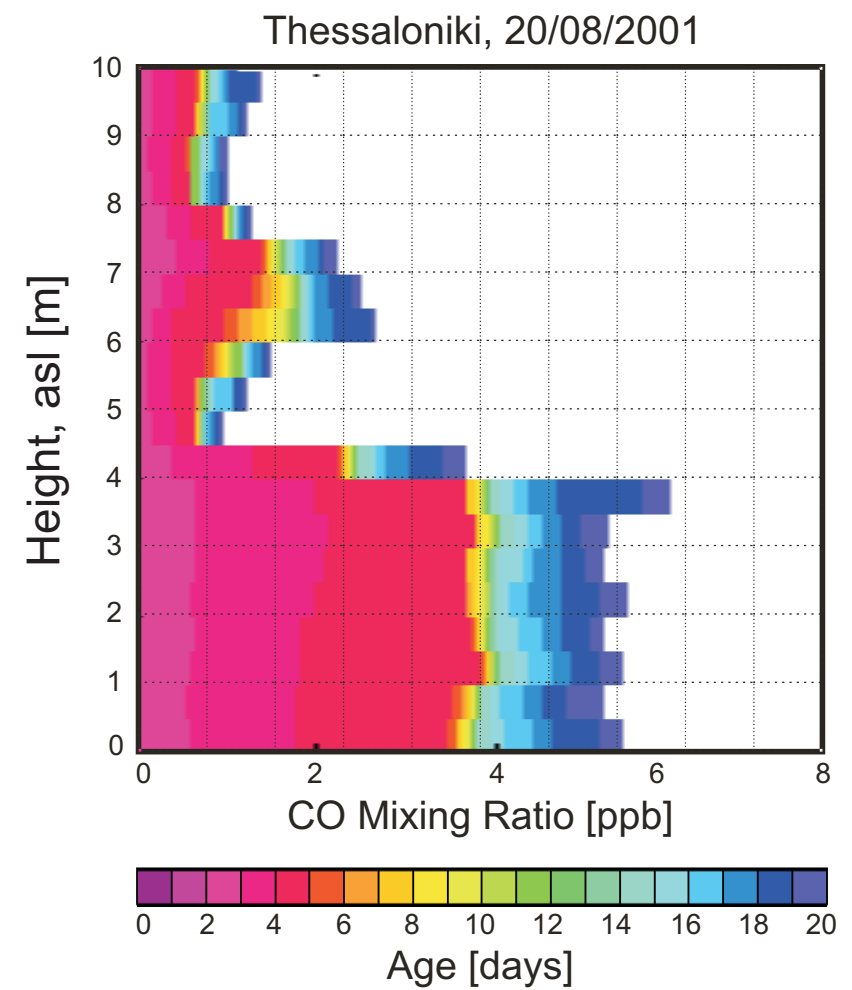

Fig. 3. Carbon monoxide concentration vertical profile over Thessaloniki for 20th of August 2001 at 18:00 UTC, from FLEXPART simulations. Model calculations were performed considering $\mathrm{CO}$ emissions only from fire hotspots detected by ATSR. The age of $\mathrm{CO}$ is indicated by the color bar.

was run backward in time from the smoke layers over Thessaloniki, as those detected by the lidar profiles. According to Fig. 2 for the 20th of August 2001, the vertically integrated emission sensitivity shows a maximum over Bulgaria and Ukraine, where the retroplume was located approximately on days 1 and 2, backward in time. As one can see in Fig. 2, the regions with the largest emission sensitivity are regions with strong fire activity. The hot spots detected by ATSR are superimposed on the column-integrated emission sensitivity map only in grid cells where the daily column-integrated emission sensitivity on the very day of the hot spot identification is above $8 \mathrm{~ns} \mathrm{~m} / \mathrm{kg}$, indicating the significant possibility of smoke advection.

To estimate the age of the smoke air mass detected by our lidar measurements, FLEXPART simulations have been used for the estimation of a carbon monoxide (CO) tracer profile over Thessaloniki. An example is presented in Fig. 3 for the 20th of August 2001 at 18:00 UTC. CO concentration profiles have been estimated with the assumption of $\mathrm{CO}$ emissions originating only from fires. Based on ATSR hotspot detection, CO emissions were calculated using Eq. (1). For these calculations we have assumed a fraction of the biomass consumed by the fire equal to 600 ha/hotspot, which in gen-

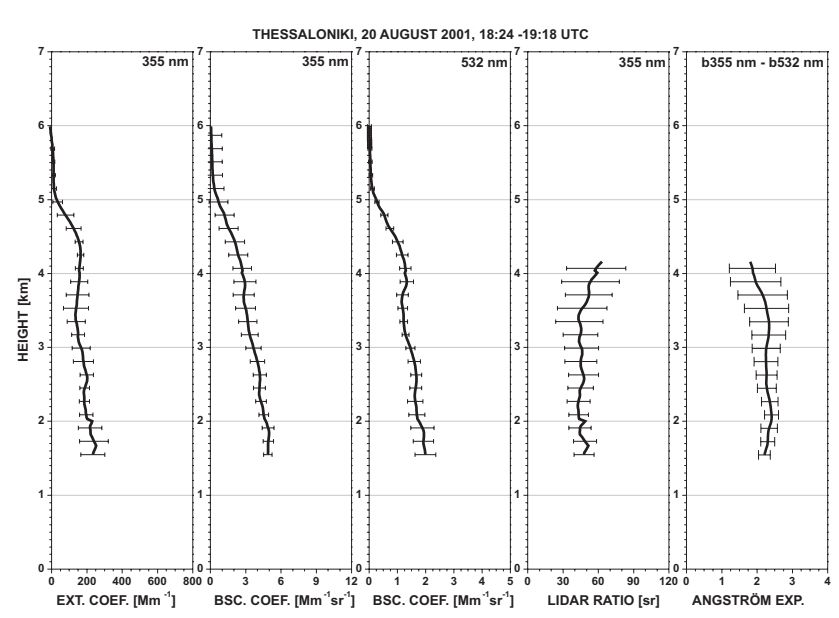

Fig. 4. Lidar derived vertical profiles of the extinction coefficient at $355 \mathrm{~nm}$, the backscatter coefficients at 355 and $532 \mathrm{~nm}$ along with the lidar ratio at $355 \mathrm{~nm}$ and the backscatter-related Ångström exponent measured at Thessaloniki on 20th of August 2001, between 18:24 and 19:18 UTC.

eral is considered a low estimation. This value was subjectively determined, since no information on how much area was actually burned per detected hotspot is available. The uncertainties in $\mathrm{CO}$ fire emissions in our calculations are even larger due to the limited capability of ATSR to correctly detect agricultural fires. For these two reasons, the final simulated $\mathrm{CO}$ vertical distributions from biomass burning activities used in this study might be rather low in absolute concentration terms. However, under-estimation of $\mathrm{CO}$ should not affect our study, since in the following we will use only relative differences between the ten days of simulations. This under-estimation must be of common magnitude for all cases examined due to the linearity of Eq. (1) and changes in the constant parameters assumed would only scale CO concentrations to higher values, affecting only the absolute values of the simulated relative vertical distributions.

For the ten days of the smoke advection over Thessaloniki as indicated from dispersion calculations, we have calculated the extinction and backscatter coefficient profiles from the measured Raman lidar signal at $355 \mathrm{~nm}$ and the elasticbackscatter signals at 355 and $532 \mathrm{~nm}$. As an example we present in Fig. 4 these profiles together with the derived lidar ratio at $355 \mathrm{~nm}$ and the backscatter-related Ångström exponent (calculated from 355 and $532 \mathrm{~nm}$ backscatter coefficients) for the 20th of August 2001, between 18:24 and 19:18 UTC. The error bars indicate statistical errors corresponding to signal averaging. The backscatter maximum at both wavelengths for that case was observed within the 1.5 and $4.5 \mathrm{~km}$ height range. This aerosol layer showed quite a stable maximum during the measurement period. The lidar ratio was almost constant with an average value of $47.6 \pm 4.6 \mathrm{sr}$. The lack of significant vertical variability of the lidar ratio suggests the presence of aerosol of the same 


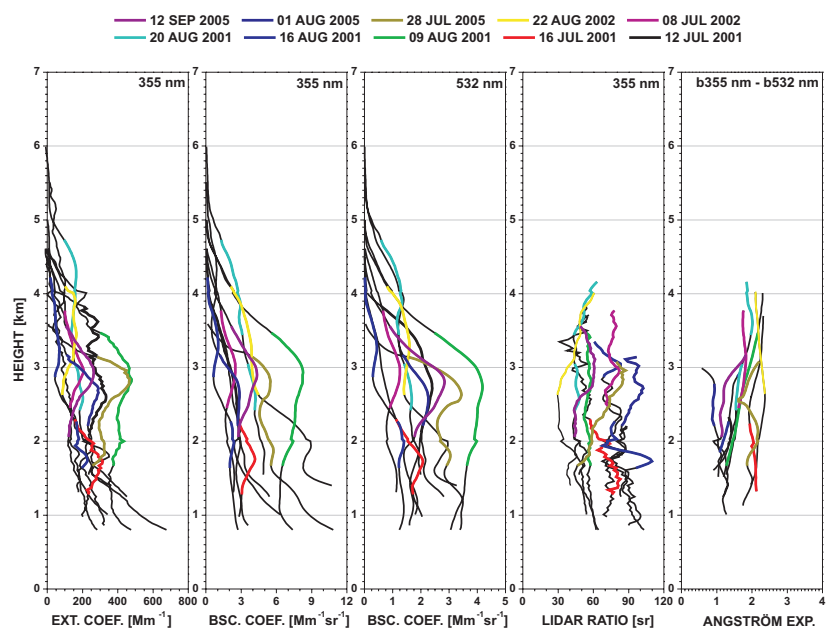

Fig. 5. Lidar derived vertical profiles of the extinction coefficient at $355 \mathrm{~nm}$, the backscatter coefficients at 355 and $532 \mathrm{~nm}$ along with the lidar ratio at $355 \mathrm{~nm}$ and the backscatter-related Angström exponent measured at Thessaloniki for ten days that smoke presence was detected. Black lines correspond to the complete vertical profile measured for each day while height ranges indicated with different colour correspond to the smoke layers.

type throughout this layer. Backscatter-related Ångström exponent for the same height range was found to be equal to $2.25 \pm 0.16$. Hence the lidar profiles, the dispersion modeling results shown in Figs. 2 and 3 and additional trajectory analysis (not shown here) confirmed that air masses in the height region between 1.5 and $4.5 \mathrm{~km}$ originated solely from regions with biomass burning activity, suggesting the presence of smoke particles in the free troposphere over Thessaloniki.

The above presented analysis for the 20th of August 2001 was repeated for the entire ten day data-set discussed in this paper, where smoke advection over Thessaloniki was strongly indicated by the synergy of lidar measurements and dispersion modeling. Vertical profiles of the extinction coefficient ( $355 \mathrm{~nm})$, backscatter coefficient ( 355 and $532 \mathrm{~nm}$ ), lidar ratio $(355 \mathrm{~nm})$ and backscatter-related Ångström exponent $(355 / 532 \mathrm{~nm})$ referring to smoke particles for the days discussed are presented in Fig. 5. The dates follow the same colour-code as the profiles on the figure. Smoke layers, as they have been identified by emission sensitivities calculated for different arrival heights above the station, are indicated with different colour for each day. Only the smoke layers are indicated with colours, while black lines correspond to the complete vertical profile measured for each day. The lidar ratio for smoke particles found to vary between 32 and 103 sr. The backscatter-related Ångström exponent ranged between 0.5 and 2.4. It has to be emphasized here, that backscatterrelated Ångström Exponent values presented in this paper are not directly retrieved by measurements, since the backscatter profile at $532 \mathrm{~nm}$ used for the calculations is retrieved after

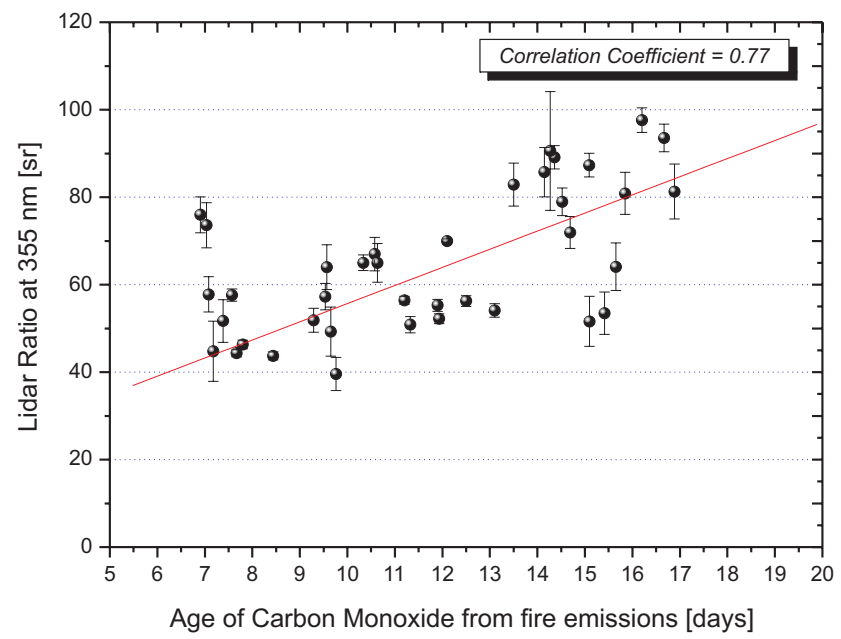

Fig. 6. Vertical mean values of the lidar ratio at $355 \mathrm{~nm}$ versus weighted mean age of the carbon monoxide tracer, calculated for height ranges of smoke presence.

the assumption of an unknown vertically constant lidar ratio. However, even if affected by a large uncertainty due to lidar ratio assumption, backscatter-related Ångström Exponent can still provide an indication about the size of the particles.

The variability of the lidar ratio and backscatter-related Ångström exponent for smoke particles cannot be attributed to different source characteristics, since for the case studies discussed here the main and common source of smoke is the agricultural fires in Russia and Ukraine. In this region, farmers burn each year the crop stubble off recently harvested fields in anticipation of the next sowing. The variability of the optical parameters can be attributed to the fact that the fire regions were located in variable distances from Thessaloniki which affects the optical characteristics of the observed smoke aerosols due to different ageing processes, depending also to the meteorological conditions responsible for the speed of the smoke plume.

To investigate the variability of the lidar derived optical parameters during the days of our interest we attempted to estimate the relative age of the air mass, by calculating weighted averages of the $\mathrm{CO}$ age over Thessaloniki from the model estimated vertical profiles based on fire emissions (shown in Fig. 3 for the example of 20th of August 2001). Only the height ranges with smoke presence identified both by lidar measurements and FLEXPART simulations were considered. For the calculation of the mean age of $\mathrm{CO}$ from biomass burning activities, the $\mathrm{CO}$ concentrations were used as weights. Calculated age averages are plotted against vertical mean values of the lidar ratio binned at $0.5 \mathrm{~km}$ in Fig. 6. A correlation of the order of 0.77 was found for the vertical mean values of the lidar ratio and the relative age of the air mass. This figure suggests that the lidar ratio for smoke particles under investigation is a 
function of the age of the particles. In general, the lidar ratio can be calculated by Raman lidars that can perform independent measurement of backscatter and extinction profiles (Ansmann et al., 1992) and High Spectral Resolution Lidars (HSRL) (Fiocco et al., 1971). However, most lidars used in aerosol research are elastic-backscatter lidars and in that case, the lidar ratio is an important parameter for the determination of the particle backscatter coefficient from the elastic-backscatter signal alone. New space-borne missions like the Cloud-Aerosol Lidar and Infrared Pathfinder Satellite Observation (CALIPSO) need the lidar ratio information to invert the elastic-backscatter signals to reliable backscatter profiles. The lidar ratio for backscatter lidar inversions is usually being hypothesized based on aerosol type assumption. Usually, the aerosol type is assumed based on synergetic satellite data and modeling aerosol source estimations (for e.g. air-mass trajectories). Additional lidar parameters measured, like the depolarization ratio and the backscatterrelated Ångström exponent (for multi-wavelength backscatter lidars) could be synergistically used to characterize the aerosol type. However, the choice of a representative constant lidar ratio for a specific aerosol type could be a large source of uncertainty in backscatter retrievals. As we are showing here, the lidar ratio is variable for smoke particles, depending mainly on the age of the air mass. Specifically for the case of smoke particles, Reid et al. (1998) suggested that if just one optical property of the particles is measured, then some of the other properties of the particles, such as particle size distribution parameters and single-scattering albedo, can be deduced. In this paper we apply this suggestion for the lidar ratio. For smoke particles and in the case of elasticbackscatter lidar (e.g. CALIPSO), one can estimate the age of the air mass from model runs (e.g. the age of the $\mathrm{CO}$ tracer) and then, assume a specific value for the lidar ratio based on the aerosol type. In this paper we demonstrated that the lidar ratio for smoke under investigation vary with the age of the air mass. The choice of the lidar ratio for the retrieval of backscatter profiles from multi-wavelength backscatter lidars can be improved using relationships extracted by groundbased Raman lidar measurements of a specific aerosol type like the one presented in Fig. 6. However, we have to mention that the choice of the lidar ratio is more complicated in mixed aerosol states. The state of mixing and the age of the air mass are the reasons that the lidar ratio is not constant since this parameter is dependent on the size distribution and the refractive index. Only in a well defined aerosol layer of a specific type, the lidar ratio can be assumed based on groundbased Raman lidar measurements.

In regard to the smoke aerosol size, there is strong evidence from observations of biomass-burning plumes in different regions of the world that particles grow in size during the ageing of the plumes, (e.g., Fiebig et al., 2003). Processes that lead to the increase of particle size are, gas-toparticle conversion of inorganic and organic vapors (Reid and Hobbs, 1998; Reid et al., 1998), condensation of large organic molecules from their gas phase in the first few hours of ageing (Reid and Hobbs, 1998; Pósfai et al., 2004), particle growth due to coagulation (Westphal and Toon, 1991; Fiebig et al., 2003), and photochemical and cloud-processing mechanisms. Liousse et al. (1995) found a significant increase of particle size with age of plumes that originated from savannah fires in Ivory Coast in Africa. A decrease of the Ångström exponent (450-550 nm wavelength), which is equivalent to an increase of particle size was observed for fires in tropical forest and cerrado during SCAR-B campaign (Reid et al., 1998). In situ observations showed that Ångström exponents were on the order of $2.2 \pm 0.2$ for fresh smoke and $1.2 \pm 0.2$ for aged smoke.

The values for aged smoke are very similar to the values reported here for the backscatter-related Ångström exponent (355-532 nm wavelength) calculated from lidar observations. As we already mentioned, the backscatter-related Ångström exponent values presented in this paper are not directly retrieved by measurements, since the backscatter profile at $532 \mathrm{~nm}$ used for the calculations is retrieved after the assumption of an unknown vertically constant lidar ratio. However, backscatter-related Ångström exponent values were validated against the extinction-related Ångström exponent values taken from sunphotometric measurements (350-400 nm), showing a correlation coefficient of 0.94 for the 10 studied cases and as such they are considered trustworthy. We have to additionally mention that CALIOP lidar instrument on board of CALIPSO satellite aims to provide backscatter-related Angstrom Exponent values in a global scale operating with 2 backscatter channels. In this paper, we demonstrate the potential of a ground-based lidar to provide Lidar Ratios to be used by the space-borne lidar. Providing a possible relationship between Lidar Ratio and backscatter-related Angstrom Exponent for specific aerosol types, CALIPSO's algorithms could improve their retrievals by choosing an appropriate lidar ratio for the retrievals based on its own CALIPSO estimations of the backscatter-related Ångström exponent.

In Fig. 7 we present the vertical mean values of the lidar ratio (up) and the weighted mean age of the air mass (down) against our estimated backscatter-related Ångström exponent values, binned at $0.5 \mathrm{~km}$. A shift of particle size toward larger values is indicated by Fig. 7, since Ångström exponents decrease with the age of the air mass. This can be attributed to a systematic shift of particle size toward larger values with increasing distance from the source of fires. Additionally, lidar ratios are larger for larger particles. Lidar observations of an aged biomass-burning plume that had originated from western Canada in 1998 and which was observed over Germany during the Lindenberg Aerosol Characterization Experiment (LACE) 98 showed that the Ångström exponent was as small as 0.06 which indicates well-aged smoke particles even larger than the ones found in this study (Fiebig et al., 2002; Wandinger et al., 2002). Dual-wavelength Raman lidar observations of Siberian forest fire smoke were carried 


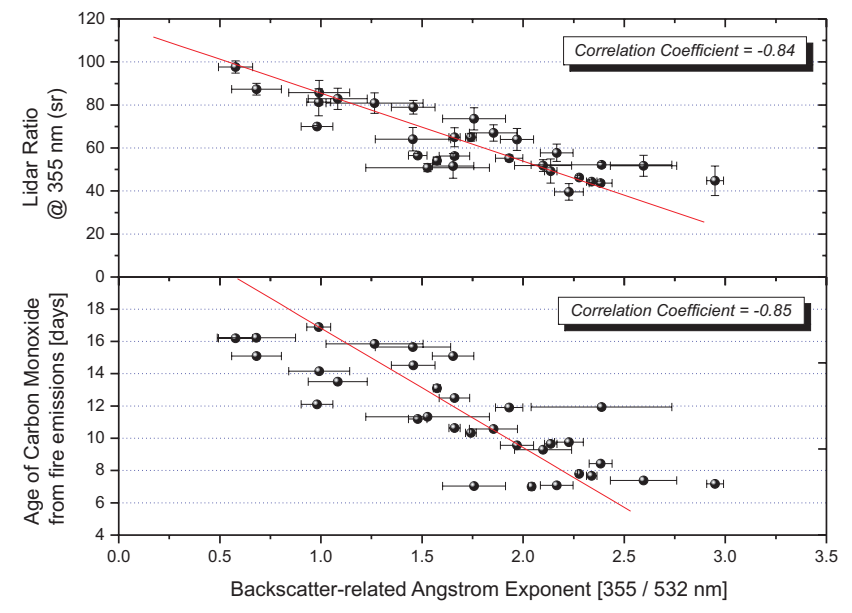

Fig. 7. (Up) Vertical mean values of the Lidar Ratio versus the backscatter-related Ångström exponent estimated from the backscatter coefficients at 355 and $532 \mathrm{~nm}$, calculated for height ranges of smoke presence. (Down) Vertical mean values of the weighted mean age of the carbon monoxide tracer versus the backscatter-related Angström exponent estimated from the backscatter coefficients at 355 and $532 \mathrm{~nm}$, calculated for height ranges of smoke presence.

out at Tokyo on 21 May 2003 (Murayama et al., 2004). Smaller particles than those observed in Leipzig on 29 May 2003 were found with an Ångström exponent on the order of 1.35. It has to be emphasized here that the extinction-related and the backscatter-related Ångström exponents can differ and a direct comparison between these parameters is not in general appropriate. However, it has been shown by Müller et al. (2005) that the lidar ratio at 355 and $532 \mathrm{~nm}$ for smoke particles is almost equal. No spectral variability of the lidar ratio is mathematically translated to the equivalent of the Ångström exponents for the extinction and the backscatter. Finally, we have to mention that the fires described here and the fires discussed in the cited literature, certainly have different properties. Thus, conclusions regarding the increase of particle size with ageing have to be treated with caution to each case (depending on source characteristics) and are subject for future studies.

\section{Summary and conclusions}

In this paper, Raman lidar measurements for ten selected cases during 2001-2005, when air masses were advected over Thessaloniki from regions with intense fire activity, have been presented, in terms of extinction $(355 \mathrm{~nm})$ and backscatter coefficient ( 355 and $532 \mathrm{~nm}$ ) and the corresponding lidar ratio $(355 \mathrm{~nm})$ and backscatter-related Ångström exponent $(355 / 532 \mathrm{~nm})$. Lidar ratios in the range of 32-103 sr were observed for smoke particles, while the backscatterrelated Ångström exponent varied between 0.5 and 2.4.
Knowledge of the optical properties of smoke in Southeastern Europe is very important for climatic studies, taking also into account the increasing trend of fires during the last decade. It was found that the optical characteristics of smoke aerosol were variable and this behaviour was mainly attributed to the fact that the burned regions are located in variable distances from the lidar station of Thessaloniki which affects the optical characteristics of the advected observed smoke aerosols due to different ageing processes. To justify this assumption we compared the lidar ratio at $355 \mathrm{~nm}$ (directly measured) and the backscatter-related Ångström exponent (estimation), which is mainly depended on particle size, with dispersion model estimations of the mean age of the carbon monoxide produced by the fires and advected over our site. Our results show that particle size is likely to increase with the age of the advected air mass. The increase of smoke particle size with age has fundamental implications for climate modeling and could be combined with modeling efforts to better constrain the radiative effect of biomass burning aerosols on regional/global scales. Finally, the correlation of the lidar ratio with the age of the air mass and the size of the particles found in this study is considered valuable information to be used by backscatter lidar inversion algorithms in case of smoke presence for reducing uncertainty in the aerosol backscatter coefficient determination due to the lidar ratio assumption, starting from a simply elastic backscatter lidar as the first satellite-borne operation lidar CALIPSO. However, we have to mention that the agricultural fires described here could not be representative for all fires and the whole globe. Thus, conclusions regarding the increase of lidar ratio with ageing have to be treated with caution to each case (depending on source characteristics) and are subject for future studies.

Acknowledgements. This work was funded by the European Commission in the framework of the EARLINET (EVR1CT1999-40003) project. The fire position data (hot spots) were obtained from ATSR World Fire Atlas (European Space Agency ESA/ESRIN). EG acknowledges the support of the GSRT-PENED project. SK acknowledges the Research Committee of the Aristotle University of Thessaloniki for the excellence award in "Investigation of aerosol concentration in Thessaloniki area with the use of ground/based and satellite measurements".

Edited by: A. Nenes

\section{References}

Abel, S. J., Haywood, J. M., Haywood, E. J., Li, J., and Buseck, P. R.: Evolution of biomass burning aerosol properties from an agricultural fire in southern Africa, Geophys. Res. Lett., 30(15), 1783, doi:10.1029/2003GL017342, 2003.

Amiridis, V., Balis, D. S., Kazadzis, S., Bais, A., Giannakaki, E., Papayannis, A., and Zerefos, C.: Four-year aerosol observations with a Raman lidar at Thessaloniki, Greece, in the framework 
of European Aerosol Research Lidar Network (EARLINET), J. Geophys. Res., 110, D21203, doi:10.1029/2005JD006190, 2005.

Andreae, M. O., Fishmanm, J., Lindesay, J., et al.: The Southern Tropical Atlantic Region experiment (STARE): transport and atmospheric chemistry near the Equator - Atlantic (TRACE-A) and Southern African fire/atmosphere research initiative (SAFARI): an introduction, J. Geophys. Res., 101, 23519-23520, 1996.

Ansmann, A., U. Wandinger, M. Riebesell, et al.: Independent measurement of extinction and backscatter profiles in cirrus clouds using a combined Raman elastic-backscatter lidar, Appl. Opt., 31, 7113, 1992.

Balis, D., Papayannis, A., Galani, E., Marenco, F., Santacesaria, V., Hamonou, E., Chazette, P., Ziomas, I., and Zerefos, C.: Tropospheric LIDAR aerosol measurements and Sun photometric observations at Thessaloniki, Greece, Atmos. Environ., 34, 925932, 2000

Balis, D., Amiridis, V., Zerefos, C., and Papayannis, A.: Verification of the experimental determination of the lidar overlap profile by a Raman lidar, paper presented at International Laser Radar Conference, Def. Res. and Dev. Can., Quebec, BC, Canada, 2002

Balis, D., V. Amiridis, C. Zerefos, et al.: Raman lidar and Sunphotometric measurements of aerosol optical properties over Thessaloniki, Greece during a biomass burning episode, Atmos. Environ., 37, 4529-4538, 2003.

Böckmann, C., Wandinger, U., Ansmann, A., et al.: Aerosol lidar intercomparison in the framework of the EARLINET project: 2. Aerosol backscatter algorithms, Appl. Opt., 43, 977-989, 2004.

Bösenberg, J., Wandinger, U., Ansmann, A., et al.: EARLINET: A European Aerosol Research Lidar Network to establish an aerosol climatology, Max Planck Inst. for Meteorol., Hamburg, Germany, Rep. 348, 155-158, 2003.

Dozier, J.: A method for satellite identification of surface temperature fields of subpixel resolution, Remote Sens. Environ., 11, 221-229, 1981.

Eck, T. F., Holben, B. N., Ward, D. E., et al.: Characterization of the optical properties of biomass burning aerosols in Zambia during the 1997 ZIBEE field campaign, J. Geophys. Res., 106, 34253448, 2001.

Ferrare, R. A., Fraser, R., and Kaufman, Y. J.: Satellite measurements of large-scale air pollution: measurements of forest fire smoke, J. Geophys. Res., 95, 9911-9925, 1990.

Fiebig, M., Petzold, A., Wandinger, U., Wendisch, M., Kiemle, C., Stifter, A., Ebert, M., Rother, T., and Leiterer, U.: Optical closure for an aerosol column: Method, accuracy, and inferable properties, applied to a biomass-burning aerosol and its radiative forcing, J. Geophys. Res., 107(D21), 8130, doi:10.1029/2000JD000192, 2002.

Fiebig, M., Stohl, A., Wendisch, M., Eckhardt, S., and Petzold, A.: Dependence of solar radiative forcing of forest fire aerosol on ageing and state of mixture, Atmos. Chem. Phys., 3, 3881-3891, 2003 ,

http://www.atmos-chem-phys.net/3/3881/2003/.

Fiocco, G., Benedetti-Michelangeli, G., and Maischberger, K.: Measurement of temperature and aerosol to molecule ratio in the troposphere by optical radar, Nature, 229, 78, 1971.

Forster, P., Ramaswamy, V., Artaxo, P., et al.: Changes in Atmospheric Constituents and in Radiative Forcing, in: Climate
Change 2007: The Physical Science Basis. Contribution of Working Group I to the Fourth Assessment Report of the Intergovernmental Panel on Climate Change, edited by: Solomon, S., Qin, D., Manning, M., Chen, Z., Marquis, M., Averyt, K. B., Tignor, M., and Miller, H. L., Cambridge University Press, Cambridge, UK and New York, NY, USA, 2007.

Hansen, M., DeFries, R., Townshend, J. R. G., and Sohlberg, R.: Global land cover classification at $1 \mathrm{~km}$ resolution using a decision tree classifier, Intern. J. Remote Sens., 21, 1331-1365, 2000.

Hobbs, P. V., Reid, J. S., Herring, J. A., et al.: Particle and trace gas measurements in the smoke from prescribed burns of forest products in the Pacific Northwest, in: Biomass Burning and Global Change, edited by: Levine, J. S. MITPress, Cambridge, MA, USA, 697-715, 1996.

Hobbs, P. V., Reid, J. S., Herring, J. A., et al.: Particle and trace-gas measurements in the smoke from prescribed burns of forest products in the Pacific Northwest, in Biomass Burning and Global Change, edited by: Levine, J. S., MIT Press, Cambridge, MA., USA, 697-715, 1997.

Intergovernmental Panel on Climate Change (IPCC), Climate Change 2001: The Science of Climate Change, Technical Summary of the Working Group I Report, Cambridge Univ. Press, New York, 2001.

Kasischke, E. S. and Bruhwiler, L. P.: Emissions of carbon dioxide, carbon monoxide, and methane from boreal forest fires in 1998, J. Geophys. Res., 108(D1), 8146, doi:10.1029/2001JD000461, 2003.

Kaufman, Y. J., Setzer, A., Ward, D., et al.: Biomass burning airborne and spaceborne experiment in the Amazonas (BASE-A), J. Geophys. Res., 97, 14581-14599, 1990.

Kaufman, Y. J., Hobbs, P. V., Kirchhoff, V. W. J. H., et al.: Smoke, clouds, and radiationBrazil (SCAR-B) experiment, J. Geophys. Res., 103, 31783-33808, 1998.

Korontzi, S., McCarty, J., Loboda, T., et al.: Global distribution of agricultural fires in croplands from 3 years of Moderate Resolution Imaging Spectroradiometer (MODIS) data, Global Biogeochem. Cy., 20, doi:10.1029/2005GB002529, 2006.

Liousse, C., Devaux, C., Dulac, F., et al.: Aging of savanna biomass burning aerosols: Consequences on their optical properties, J. Atmos. Chem., 22, 1-17, 1995.

Matthias, V., Freudenthaler, V., Amodeo, A., et al.: Aerosol lidar intercomparison in the framework of EARLINET project: 1 . Instruments, Appl. Opt., 43, 961-976, 2004.

Mattis, I., Ansmann, A., Wandinger, U., and Müller, D.: Unexpectedly high aerosol load in the free troposphere over central Europe in spring/ summer 2003, Geophys. Res. Lett., 30(22), 2178 , doi:10.1029/2003GL018442, 2003.

Müller, D., Mattis, I., Wandinger, U., Ansmann, A., Althausen, D., and Stohl, A.: Raman lidar observations of aged Siberian and Canadian forest fire smoke in the free troposphere over Germany in 2003: Microphysical particle characterization, J. Geophys Res., 110, D17201, doi:10.1029/2004JD005756, 2005.

Murayama, T., Mller, D., Wada, K., et al.: Characterization of Asian dust and Siberian smoke with multi-wavelength Raman lidar over Tokyo, Japan in spring 2003, Geophys. Res. Lett., 31, L23103, doi:10.1029/2004GL021105, 2004.

Pappalardo, G., Amodeo, A., Pandolfi, M., et al.: Aerosol lidar intercomparison in the framework of the EARLINET project: 3. Raman lidar algorithm for aerosol extinction, backscatter, and 
lidar ratio, Appl. Opt., 43, 5370-5385, 2004.

Patterson, E. M. and McMahon, C. K.: Absorption characteristics of forest fine particulate matter, Atmos. Environ., 18, 2541-2551, 1984.

Pósfai, M., Gelencsér, A., Simonics, R., Arató, K., Li, J., Hobbs, P. V., and Buseck, P. R.: Atmospheric tar balls: Particles from biomass and biofuel burning, J. Geophys. Res., 109, D06213, doi:10.1029/2003JD004169, 2004.

Reid, J. S. and Hobbs, P. V.: Physical and optical properties of young smoke from individual biomass fires in Brazil, J. Geophys. Res., 103, 32013-32030, 1998.

Reid, J. S., Hobbs, P. V., Ferek, R. J., Blake, D. R., Martins, J. V., Dunlap, M. R., and Liousse, C.: Physical, chemical, and optical properties of regional hazes dominated by smoke in Brazil, J. Geophys. Res., 103, 32059-32080, 1998.

Reid, J. S., Koppmann, R., Eck, T. F., and Eleuterio, D. P.: A review of biomass burning emissions part II: intensive physical properties of biomass burning particles, Atmos. Chem. Phys., 5, 799825, 2005a, http://www.atmos-chem-phys.net/5/799/2005/.

Reid, J. S., Koppmann, R., Eck, T. F., et al.: A review of biomass burning emissions part III: intensive optical properties of biomass burning particles, Atmos. Chem. Phys., 5, 827-849, $2005 b$, http://www.atmos-chem-phys.net/5/827/2005/.

Seibert, P. and Frank, A.: Source-receptor matrix calculation with a Lagrangian particle dispersion model in backward mode, Atmos. Chem. Phys., 4, 51-63, 2004, http://www.atmos-chem-phys.net/4/51/2004/.

Seiler, W. and Crutzen, P. J.: Estimates of gross and net fluxes of carbon between the biosphere and atmosphere from biomass burning, Clim. Change, 2, 207-247, 1980.

Stohl, A., Hittenberger, M., and Wotawa, G.: Validation of the Lagrangian particle dispersion model FLEXPART against large scale tracer experiment data, Atmos. Environ., 32, 4245-4264, 1998.

Stohl, A., Forster, C. Eckhardt, S., Spichtinger, N., Huntrieser, H., Heland, J., Schlager, H., Wilhelm, S., Arnold, F., and Cooper, O.: A backward modeling study of intercontinental pollution transport using aircraft measurements, J. Geophys. Res., 108, 4370, doi:10.1029/2002JD002862, 2003.
Stohl, A., Forster, C., Frank, A., Seibert, P., and Wotawa, G.: Technical Note: The Lagrangian particle dispersion model FLEXPART version 6.2, Atmos. Chem. Phys., 5, 2461-2474, 2005, http://www.atmos-chem-phys.net/5/2461/2005/.

Stohl, A., Berg, T., Burkhart, J. F., Fjæraa, A. M., Forster, C., Herber, A., Hov, Ø., Lunder, C., McMillan, W. W., Oltmans, S., Shiobara, M., Simpson, D., Solberg, S., Stebel, K., Ström, J., Tørseth, K., Treffeisen, R., Virkkunen, K., and Yttri, K. E.: Arctic smoke - record high air pollution levels in the European Arctic due to agricultural fires in Eastern Europe, Atmos. Chem. Phys., 7, 511-534, 2007,

http://www.atmos-chem-phys.net/7/511/2007/.

Textor, C., Schulz, M., Guibert, S., Kinne, S., Balkanski, Y., Bauer, S., Berntsen, T., Berglen, T., Boucher, O., Chin, M., Dentener, F., Diehl, T., Easter, R., Feichter, H., Fillmore, D., Ghan, S., Ginoux, P., Gong, S., Grini, A., Hendricks, J., Horowitz, L., Huang, P., Isaksen, I., Iversen, I., Kloster, S., Koch, D., Kirkevåg, A., Kristjansson, J. E., Krol, M., Lauer, A., Lamarque, J. F., Liu, X., Montanaro, V., Myhre, G., Penner, J., Pitari, G., Reddy, S., Seland, Ø., Stier, P., Takemura, T., and Tie, X.: Analysis and quantification of the diversities of aerosol life cycles within A eroCom, Atmos. Chem. Phys., 6, 1777-1813, 2006, http://www.atmos-chem-phys.net/6/1777/2006/.

Turco, R. P. and Yu, F.: Aerosol invariance in expanding coagulation plumes, Geophys. Res. Lett., 24, 1223-1226, 1997.

Wandinger U., Müller, D., Böckmann, C., et al.: Optical and microphysical characterization of biomass burning and industrial pollution aerosols from multiwavelength lidar and aircraft measurements, J. Geophys. Res., 107, doi:10.1029/2000 JD000202, 2002.

Wandinger, U. and Ansmann, A.: Experimental determination of the lidar overlap profile with Raman lidar, Appl. Opt., 41, 511514, 2002.

Westphal, D. L. and Toon, O. B.: Simulations of microphysical, radiative, and dynamic processes in a continental-scale forestfire smoke plume, J. Geophys. Res., 96, 2379-2400, 1991.

Wotawa, G., Novelli, P. C., Trainer, M., and Granier, C.: Interannual variability of summertime $\mathrm{CO}$ concentrations in the Northern Hemisphere explained by boreal forest fires in North America and Russia, Geophys. Res. Lett., 28, 4575-4578, 2001. 